\title{
胎盤内巨大血腫（Breus' mole）の一例
}

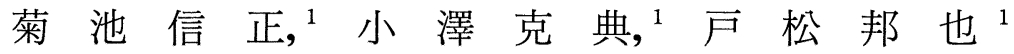

\section{要 旨}

Breus' mole は胎盤胎児側の絨毛膜の直下に生じる巨大血腫であり稀な疾患である. 本疾患は胎盤内に巨大 な血腫が生じ, 胎児胎盤の循環が損なわれ, 子宮内胎児発育遅延 (IUGR) や子宮内胎児死亡をきたす頻度が 高く, 児の予後が不良であることが多いとされている. 今回我々は, IUGR 及び妊娠中毒症を伴い出生前より Breus' mole を疑い, 生児を得ることができた症例を経験したので報告する. 症例は 38 歳の初産婦で初期より 当院外来にて経過を見ていた. 妊娠 32 週の検診時に高血圧, 蛋白尿, 浮腫を認め妊娠中毒症の診断を受け, 33 週 5 日に胎盤内に血腫の存在を認め入院管理となった. 入院時の血腫の大きさは長経 $41.6 \mathrm{~mm}$ 厚さ $38.4 \mathrm{~mm}$ の血腫であったが徐々に大きくなり, 35 週 1 日長経 $48.6 \mathrm{~mm}$ 厚さ $43.4 \mathrm{~mm}, 36$ 週 2 日胎坚仮死所見出現時には 長経 $100.6 \mathrm{~mm}$ 厚さ $100.4 \mathrm{~mm}$ まで大きくなり, 緊急帝王切開術を施行 (児 1730g, 男児, Apger score 8-10-10) 分婏となった. 胎盤は凝血魂と梗塞層が認められ, Breus' mole と診断した. (Kitakanto Med J $2003 ; 53$ : 319〜321)

キーワード : Breus' mole, 妊娠中毒症, 子宮内胎児発育遅延

はじめに

Breus' mole は, 絨毛膜板の直下に生じた巨大な絨毛膜 下血腫であり，稀な疾患である. 絨毛膜板の直下に生じ た巨大血腫を特に Breus' mole と呼び, 子宮内胎児発育 不全 (IUGR) や妊娠中毒症 (Preeclampsia) を伴うこと が多いと報告されているが巨大な血腫を形成するにもか かわらず，その出生前診断からの報告は非常に少なく文 献も多くはない. ${ }^{1,2}$ 今回我々は出生前から Breus' mole を 疑い, 厳重に経過を観察し無事に生児を得ることができ た症例を経験したので報告する。

\section{症例}

患 者：38 歳, 0 回経妊, 0 回経産.

既往歴：特記すべきことなし

家族歴：特記すべきことなし

月経歴：初経 12 歳

現病歴: 平成 14 年 3 月 7 日を最終月経として妊娠, 当 院で妊婦検診を受けていた. 初期の妊娠経過は順調で あったが, 妊娠 29 週 5 日より血圧 135/87, 尿蛋白 (土) 胎児発育 $1247 \mathrm{~g}$ と胎児発育遅延傾向が出現. 32 週 5 日血
圧 $148 / 99 \mathrm{mmHg}$, 尿蛋白 $(++)$, 胎児発育 $1468 \mathrm{~g}$ と胎児 発育遅延, 妊娠中毒症所見が現れた. 33 週 5 日血圧 141/ $94 \mathrm{mmHg}$, 尿蛋白 $(++)$, 胎児発育 $1680 \mathrm{~g}$ と今まで出現し ていなかった胎盤内に血腫の存在を認めた（血腫の大き さは長経 $41.6 \mathrm{~mm}$ 厚さ $38.4 \mathrm{~mm}$ の血腫, 図 1) ため入院管 理となった．入院後採血でも検査デー夕は正常範囲であ り，妊娠中毒症所見も血圧は 130-140/70-80 mmHg, 尿蛋 白 $(+)$ 尿定量で 73-58 $\mathrm{mg} / \mathrm{ml}$ で推移したが子宮収縮所

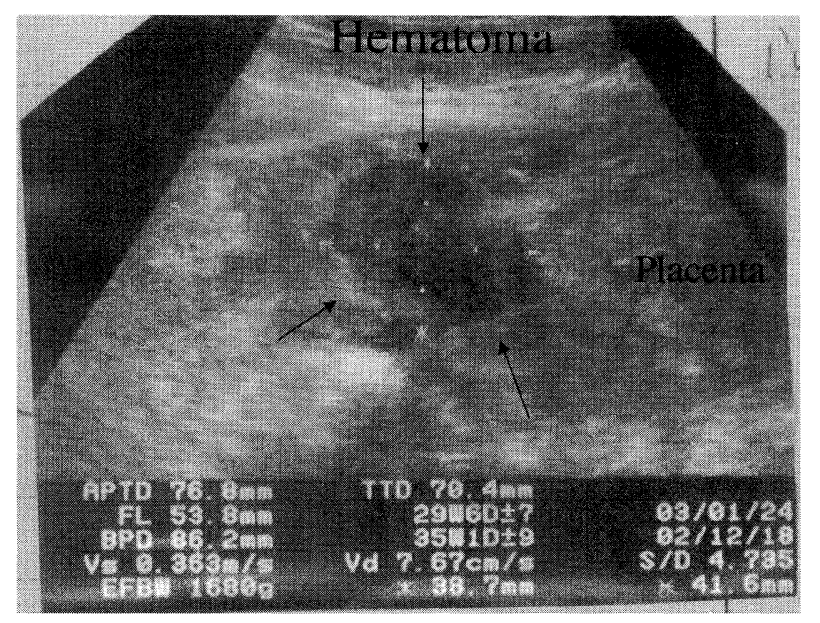

図 1 胎盤内血腫発症時の超音波像 


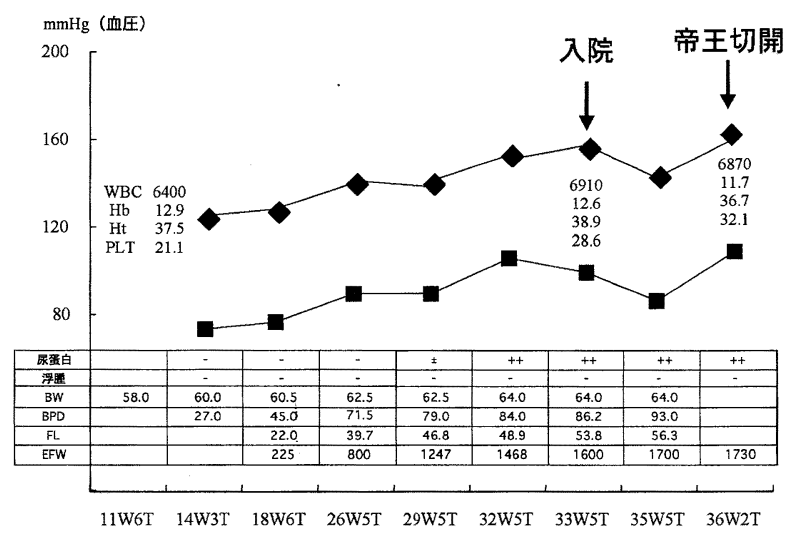

図 2 妊娠経過と臨床デー夕

BW : Body Weight BPD : Biparietal Diameter FL: Femur Length EFW : Estimate Fetal Weight

見が出現したため, 塩酸リトドリン $50 \gamma / \mathrm{hr}$ にて点滴を 開始した. 入院後, 妊娠中毒症の所見は落ち着いたがそ の後血腫の大きさは徐々に大きくなり，35 週 1 日長経 $48.6 \mathrm{~mm}$ 厚さ $43.4 \mathrm{~mm}, 36$ 週 2 日胎児仮死所見出現時には 長経 $100.6 \mathrm{~mm}$ 厚さ $100.4 \mathrm{~mm}$ まで大きくなり, 緊急帝王 切開術を施行 (児 $1730 \mathrm{~g}$, 男児, Apger score 8-10-10) 分娩 となった．胎盤は凝血魂と梗塞層が認められ，Breus’ mole と診断した. (経過については図 2 を参照).

$$
\text { 考察 }
$$

Breus’ mole は, 常位胎盤早期剝離の胎盤母体側に生じ る胎盤後血腫とは発生部位が異なり胎盤胎児側の絨毛膜 の直下にできる巨大な血腫である.1,2 Breus' mole は巨大 な血腫を形成するにもかかわらず, 臨床症状が少なく, また出生前に診断された報告は数少ない, ${ }^{3 \sim 5}$ 常位胎盤早 期剥離のような疼痛や子宮収縮など臨床的所見がそし く, また出血が起こった直後では超音波検査では輝度が ほぼ同じ状態で見えるため分りにくいことも理由にあげ られる. 本症例では, 超音波検査上低輝度を呈する部分 がほとんどであったがこの異常胎盤所見が増大している ことから徐々に出血が生じ, 血腫が増大していた可能性 が示唆できた. 胎盤に血腫が生じた場合, Breus’ moleの 可能性を考え, さらにその変化を観察することが重要と 考えられる.

過去の報告から検討すると Breus' mole の特徴として 妊娠中毒症の合併が多いこと, IUGR や羊水過少症を伴 い子宮内胎児死亡や新生児死亡などの危険性も高率であ ることが報告されている.1,2 本症例でも妊娠中毒症の合 併が認められ，過去の文献と同様な結果を辿った. Breus’ mole の発症機序として現在考えられている原因として 脱落膜内の静脈が閉塞し, 絨毛間腔内の血流が停滞, 途 絶することによって血腫を生じると推測されている. そ こに血流の停滞によって絨毛間腔内の内圧が上昇して絨
毛環流が途絶され絨毛組織内に存在する胎児胎盤血流が 破綻するという機序が考えられている. 妊娠中毒症に伴 う血液凝固亢進状態は絨毛-脱落膜静脈に血栓形成の促 進, 血流の閉塞を促すことから妊娠中毒症が Breus' mole の一因になっている可能性が強く示唆される. ${ }^{6 \sim 8}$ IUGR や羊水過少症の合併が多いのも Breus' mole の特徽の一 つだが本症例でも著明な asymmetrical IUGR が認めら れ, 羊水過少も本症例では 29 週時には AFI が 10.9 あっ たものが入院後 34 週には AFI が 6.1 と徐々に減少傾向 が認められた．過去の報告でも約 72\%に IUGR が認め られ，羊水過少は約 $36 \%$ に認められたと報告されてい る. ${ }^{1 \sim 3}$ Breus' mole では血腫により胎盤血流の阻害, 胎盤 機能の低下より IUGR や羊水過少が起きるとされてい る. Breus' mole による臍帯血流の異常の報告もあり, ${ }^{5 \sim 9}$ また，胎児心泊モニタリングによる胎児仮死所見などの 異常所見がでる可能性が高く, 緊急帝王切開になる率も 高いとされている. 本症例もこの胎児心泊モニタリング による胎児仮死所見が出現したため緊急帝王切開による 分婏方法を選択することとなった. Breus' mole の発症時 期について考察をすると発症時期は 20-25 週前後から発 見されることが多く, かなり妊娠早期から発症している 可能性が考えられる. 1 4 児の予後も週数により早期に婏 出することが多く, 子宮内胎児死亡は約半数にも及ぶと 報告されている.1 4 本症例では妊娠 32 週までは超音波 所見では発症していなく, 33 週に入った時期頃に発症し たのではないかと思われるがある程度週数を経過したお かげで胎児の成熟が進んだことと血腫発生時期の早期に 発見し経過を厳重に観察したおかげで子宮内胎児死亡に ならずにすんだものと考光りれる(表 1).

Breus' mole を発見した場合の管理については, 妊娠中 毒症や IUGR 羊水過少症などの合併症が多く, 子宮内胎 児死亡などの頻度も高いため積極的に入院管理を勧め, 超音波所見を厳重に管理し, できるかぎり児の推定体重 や妊娠週数を進めて救命可能な週数に入ったなら積極的 に分婏の方向に持っていくことが重要と思われる.また， 小児科医と特に NICU との密な連絡を取りつつ, 娩出時 期の決定をしていく必要があると思われる.

表 1 Breus' mole の特徵

(1) 臨床症状が少なく, また出生前に診断された報告は数 少ない (常位胎盤早期剝離のような疼痛や子宮収縮な ど臨床的所見がそしく)

（2）妊娠中毒症の合併が多い

（3） IUGR や羊水過少症を伴い子宮内胎児死亡や新生児死 亡などの危険性も高率

（4） 発症時期は 20-25 週前後から発見されることが多い 
文

献

1. Kim DT, Riddell DC, Welch JP, et al. : Association between Breus' mole and partial hydatidiform mole: chance or can hydropic villi precipitate placental massive subchorionic thrombosis? Pediatr Pathol Mol Med. 2002; 21: 451-459.

2. Zebielowicz D, Czajka R. : Breus' mole in case of pregnancy in 22 years old primipara-a case report. Ginekol Pol. 2001; 72 : 877-880.

3. Nishida N, Suzuki S, HamamuraY, et al. : Massive subchorionic hematoma (Breus' mole) complicated by intrauterine growth retardation. J Nippon Med Sch. 2001; 68: 54-57.

4. Ho HC. : Massive subchorionic hematoma. Arch Pathol Lab Med. 1983; $107: 438$.

5. Shanklin DR, Scott JS. Massive subchorial thrombohaematoma (Breus' mole). Br J Obstet Gynaecol. $1975 ; 82$ : 476-487.
6. Minakami H, Watanabe T, Izumi A, et al : Association of a decrease in antithrombin III activity with a prenatal elevation in aspartate aminotransferase in women with twin pregnancies: relevance to the HELLP syndrome. J Hepatol 1999; 30: 603-611.

7. Grisaru D, Lessing JB, Azem F, et al: An atypical case of hemolysis, elevated liver enzymes and low platelet count (HELLP) syndrome. Int J Gynaecol Obstet 1994; 44: 67-69.

8. Minakami H, Kohmura Y, Izumi A, et al : Relation between gestational thrombocytopenia and the syndrome of hemolysis, elevated liver enzymes, and low platelet count (HELLP syndrome). Gynecol Obstet Invest ; 1998 ; $46: 41-45$.

9. Richards DS, Bennentt BB. : Prenatal ultrasaund diagnosis of massive subchorionic thronbohematoma. Ultrasound Obstet Gynecol 1998:11 364-366

\title{
A Case of a Massive Hematoma Beneath Placenta (Breus' mole)
}

\author{
Nobumasa Kikuchi, ${ }^{1} \quad$ Katusuke Ozawa, ${ }^{1} \quad$ Kuniya Tomatu ${ }^{1}$ \\ 1 Department of Obstet \& Gynecol, Tatebayashi Kosei Hospital, 262-1 Narushima, Tatebayashi-City, Gunma \\ Japan $374-8533$
}

Breus' mole, a massive hematoma developing directly beneath the chorion on the fetal side of the placenta is a rare disease. With this disease, it is said that a massive hematoma develops in the placenta, that the fetus-placenta circulation is impaired, that the incidence of intrauterine growth retardation (IUGR) and intrauterine fetal death is high, and that fetal prognosis is often poor. This time we have encountered a case complicated by IUGR and gestosis, which was suspected of having Breus' mole before childbirth and gave birth to a live baby. A 38-year-old primigravida had been under observation at the out-patient clinic of this hospital since her first trimester. Examination at 32 weeks of gestation revealed hypertension, proteinuria and edema, so diagnosis of gestosis was made. With hematoma found in the placenta at 33 weeks and 5 days of gestation, she was admitted to this hospital. The hematoma on admission measured $41.6 \mathrm{~mm}$ in major diameter and $38.4 \mathrm{~mm}$ in thickness. It grew slowly to $48.6 \mathrm{~mm}$ in major diameter, $43.4 \mathrm{~mm}$ in thickness at 35 weeks and 1 day and $100.6 \mathrm{~mm}$ in major diameter, $100.4 \mathrm{~mm}$ in thickness at 36 weeks and 2 days when fetal asphyxia appeared. Emergency cesarean section was then performed for delivery (baby boy weighing 1730g, Apger score 8-10-10). The placenta showed clots and infarct layers, which led to the diagnosis of Breus' mole. (Kitakanto Med J $2003 ; 53: 319 \sim 321$ )

Key words : Breus' mole, Preeclampsia, IUGR 